\title{
Kołaczki (trochisci, pastilli), morsele (morsuli, tabellae) i krążki (rotulae, orbiculi) jako stałe doustne postaci leku w świetle dziewiętnastowiecznych podręczników do receptury
}

\section{Stomach lozenges (trochisci, pastilli), morsels (morsuli, tabellae) and rolls (rotulae, orbiculi) as permanent forms of medicines in the light of the $19^{\text {th }}$-century handbooks of prescriptions}

The following work concerns three selected permanent oral forms of prescription medicines: Stomach lozenges (trochisci, pastilli), morsels (morsuli, tabellae) and rolls (rotulae, orbiculi).

They were recognised as so-called medical treats (cupedia or cupediae medicae), which were also described as: goodies, sweets, spices or drugstore delicacies.

The following handbooks have been analysed: Formulare czyli nauka o sztuczném przepisywaniu lekarstw (Warsaw, 1816) written by Jan Bogumir Freyer (1778-1828), Wykład farmakomorfiki i katagrafologii (Cracow, 1851) by Fryderyk Kazimierz Skobel (1806-1876), Receptura czyli nauka pisania recept i przyrządzania podług nich lekarstw (Warsaw, 1865) by Antoni Kryszka (1818-1912). Issues concerning prescription medicines are described in the above publications.

The work concentrates on terminology, characteristics and rules of preparing prescriptions, as well as methods of their realisation.

Keywords: history of the $19^{\text {th }}$-century pharmacy, history of dosage forms Słowa kluczowe: historia farmacji, XIX w., historia postaci leku 
Postać leku jest formą, jaką nadaje się substancjom leczniczym w celu podania ich pacjentom. Leki mogą mieć postać płynną (np. roztwory), stałą (np. proszki) lub półstałą (np. maści) i być przeznaczone do stosowania wewnętrznego lub zewnętrznego. W aptekach zarówno w przeszłości, jak i obecnie sporządzane są różne postaci leku recepturowego na podstawie recept zredagowanych przez lekarzy dla indywidualnych pacjentów. Dzięki temu możliwe jest dobranie odpowiednich substancji, ich dawek i formy leku dla poszczególnych pacjentów z uwzględnieniem ich stanu chorobowego oraz wieku. Kołaczki (trochisci, pastilli), morsele (morsuli, tabellae) i krążki (rotulae, orbiculi) należały do stałych doustnych postaci leku i nie są obecnie wytwarzane w aptekach, niemniej jednak stanowią ciekawy przykład dawnych form leku. Zaliczano je do tzw. łakoci lekarskich (cupedia lub cupediae medicae) ${ }^{1}$, które określano także jako: łakotki, cukierki, przyprawy lub przysmaczki apteczne.

Analizie poddano następujące podręczniki: Formulare czyli nauka o sztuczném przepisywaniu lékarstw (Warszawa 1816), napisany przez Jana Bogumira Freyera (1778-1828)2, Wykład farmakomorfiki i katagrafologii (Kraków 1851) autorstwa Fryderyka Kazimierza Skobla (1806-1876), Receptura czyli nauka pisania recept i przyrządzania podług nich lekarstw (Warszawa 1865), który opracował Antoni Kryszka (1818-1912). W wymienionych publikacjach opisane zostały zagadnienia odnoszące się do leków recepturowych. Wszyscy autorzy podręczników prowadzili m.in. działalność dydaktyczną: prof. Freyer wykładał materię medyczną na Wydziale Akademicko-Warszawskim Nauk Lekarskich, a także patologię szczegółową i formlarae ${ }^{3}$, prof. Skobel - patologię, terapię ogólną i farmakognozję na Uniwersytecie Jagiellońskim ${ }^{4}$, a prof. Kryszka - fizjologię, farmakologię i terapię ogólną oraz materię medyczną i recepturę w Cesarsko-Królewskiej Akademii Medyko-Chirurgicznej w Warszawie, a następnie w Szkole Głównej Warszawskiej5. W XIX w. w języku polskim wydano tylko wyżej wymienione podręczniki odnoszące się do kwestii przepisywania i przyrządzania leków recepturowych.

Celem artykułu jest próba udzielenia odpowiedzi na pytanie: na czym polegały podobieństwa i różnice $\mathrm{w}$ zakresie terminologii, charakterystyki, zasad redagowania recept na postaci leku wymienione w tytule pracy oraz sposobów ich wykonywania w ujęciu autorów wybranych podręczników?

Uwagę zwraca różnorodność nazewnictwa używanego dla wybranych postaci leku. W najstarszym z analizowanych podręczników - Formulare... autorstwa Freyera dla kołaczków użyto też nazwy placuszkí. W podręczniku Skobla Wykład farmakomorfiki... kołaczki nazwane zostały również placuszkami, a także: kołaczykami, powałkami, powa-

1 Skobel nadmienił, że do tzw. łakoci lekarskich, oprócz kołaczków, morseli i krążków, należą: cukrosmażki i ciasta lekarskie (pastae) (F.K. Skobel, Wykład farmakomorfiki i katagrafologii, Kraków 1851, s. 150). Kryszka natomiast zaliczył do nich także: konserwy (conservae) i trociczki (aviculae, candelae, pastilli fumales). Wspomniał również, że dawniej wliczano do tej grupy owoce smażone w cukrze (condita) i konfitury (confectiones), oraz że obecnie tylko „w wyjątkowych razach zasługują na uwagę lekarza, gdy chodzi o dogodzenie wymaganiom, albo o pokonanie wstrętu do lekarstw, u dzieci spotykanego" (A. Kryszka, Receptura czyli nauka pisania recept i przyrządzania podług nich lekarstw, Warszawa 1865, s. 56).

2 Drugie wdanie tego podręcznika ukazało się w $1829 \mathrm{r}$.

3 Zob. Polski słownik biograficzny, t. 7, Kraków 1958, s. 134-135.

4 Zob. Polski słownik biograficzny, t. 38, Warszawa 1998, s. 203-205.

5 Zob. Polski słownik biograficzny, t. 15, Wrocław 1970, s. 495-496.

6 J.B. Freyer, Formulare czyli nauka o sztuczném przepisywaniu lekarstw, Warszawa 1816, s. 108. 
Tabela. 1. Nazewnictwo kołaczków, morseli i krążków w wybranych dziewiętnastowiecznych podręcznikach do receptury

\begin{tabular}{|c|c|c|c|c|c|c|}
\hline Postać leku & \multicolumn{2}{|c|}{ Kołaczki } & \multicolumn{2}{|c|}{ Morsele } & \multicolumn{2}{|c|}{ Krążki } \\
\hline Autor & $\begin{array}{l}\text { Nazwa } \\
\text { polska }\end{array}$ & $\begin{array}{c}\text { Nazwa } \\
\text { łacińska }\end{array}$ & $\begin{array}{l}\text { Nazwa } \\
\text { polska }\end{array}$ & $\begin{array}{c}\text { Nazwa } \\
\text { łacińska }\end{array}$ & $\begin{array}{l}\text { Nazwa } \\
\text { polska }\end{array}$ & $\begin{array}{l}\text { Nazwa } \\
\text { łacińska }\end{array}$ \\
\hline $\begin{array}{l}\text { J.B. Freyer } \\
(1816 \text { r.) }\end{array}$ & $\begin{array}{l}\text { Placuszki } \\
\text { Kołaczki }\end{array}$ & $\begin{array}{l}\text { Trochisci } \\
\text { Pastilli }\end{array}$ & $\begin{array}{l}\text { Morselle } \\
\text { Tabliczki }\end{array}$ & $\begin{array}{l}\text { Morsuli } \\
\text { Tabellae } \\
\text { W formie } \\
\text { tzw. czwo- } \\
\text { rogranów } \\
\text { ukośnych: } \\
\text { Tessellae } \\
\text { Lozangiae }\end{array}$ & $\begin{array}{l}\text { Kółeczka } \\
\text { Krążki }\end{array}$ & \begin{tabular}{|l|} 
Rotulae \\
Orbiculi
\end{tabular} \\
\hline \begin{tabular}{|l} 
F.K. Skobel \\
$(1851$ r.)
\end{tabular} & \begin{tabular}{|l|} 
Kołaczki \\
Kołaczyki \\
Powałki \\
Powałaeczki \\
Powałuszki \\
Placuszki \\
Trociszki \\
\end{tabular} & \begin{tabular}{|l|} 
Trochisci \\
Pastilli
\end{tabular} & $\begin{array}{l}\text { Morsele } \\
\text { Morszele } \\
\text { Morselki } \\
\text { Tabliczki }\end{array}$ & \begin{tabular}{|l|} 
Morsuli \\
Tabellae \\
Dawniej: \\
Electuaria \\
solida \\
Electuaria \\
sicca \\
\end{tabular} & \begin{tabular}{|l|} 
Krążki \\
Kółeczka
\end{tabular} & \begin{tabular}{|l|} 
Rotulae \\
Orbiculi
\end{tabular} \\
\hline $\begin{array}{l}\text { A.Kryszka } \\
\text { (1865 r.) }\end{array}$ & $\begin{array}{l}\text { Kołaczki } \\
\text { Pastylki }\end{array}$ & \begin{tabular}{|l} 
Trochisci \\
Pastilli \\
Lozangiae
\end{tabular} & \begin{tabular}{|l|} 
Kąski \\
Morsulki
\end{tabular} & \begin{tabular}{|l|} 
Morsuli \\
Tabellae \\
Tesselae \\
Dawniej: \\
Electuaria \\
sicca
\end{tabular} & Krążki & $\begin{array}{l}\text { Rotulae } \\
\text { Orbiculi }\end{array}$ \\
\hline
\end{tabular}

Źródło: J.B. Freyer, op. cit. s. 108, 114, 117; F.K. Skobel, op. cit. s. 148, 154, 158; A. Kryszka, op. cit. s. $56,57,58,59,60$.

łeczkami, powałuszkami oraz trociszkami. Kryszka w książce Receptura... dla kołaczków, oprócz nazw w języku łacińskim trochisci, pastilli (stosowanych też przez wymienionych powyżej autorów), wymienił także: lozangiae. Warto również nadmienić, że spośród wybranych autorów tylko Kryszka użył do określenia kołaczków słowa pastylki ${ }^{8}$.

Kolejna postać leku - morsele - w opracowaniu Freyera określone zostały jako morselle (morsuli) oraz tabliczki (tabellae) ${ }^{9}$. Skobel dla tej postaci leku wymienił też nazwy: morszele, morselki, tabliczki, zaznaczając, że dawniej stosowano także: electuaria solida, electuaria sicca ${ }^{10}$. Natomiast Kryszka podał określenia: kąski, morsulki oraz w języku łacińskim: morsuli, tabellae, tesselae, nadmieniając, że dawniej używano również sformułowania electuaria sicca ${ }^{11}$.

W przypadku postaci leku nazywanej w języku łaciński rotulae lub orbiculi wszyscy autorzy zastosowali nazwę polską - krążki, przy czym Freyer i Skobel użyli też określenia kółeczka ${ }^{12}$.

Zestawienie nazewnictwa opisywanych form leku, używanego w wybranych podręcznikach, zamieszczono $w$ tabeli 1.

7 F.K. Skobel, op. cit., s. 148.

8 W sformułowaniu: „Z soli wód mineralnych wyrabiają pastylki wiszy, bilińskie, napojone niekiedy aromatami” (A. Kryszka, op. cit., s. 60).

9 J.B. Freyer, op. cit., s. 114.

10 F.K. Skobel, op. cit., s. 158.

11 A. Kryszka, op. cit., s. 56.

12 J.B. Freyer, op. cit., s. 117; F. K. Skobel, op. cit., s. 154; A. Kryszka, op. cit., s. 58 
Wspólną i najważniejszą substancję pomocniczą we wszystkich wymienionych postaciach leku stanowiła sacharoza, określana w wybranych podręcznikach nazwą cukier. Szymon Fabian (1802-1885) w swojej książce poświęconej surowcom leczniczym podał, że Saccharum album (cukier biały), stosowany do wytwarzania leków, otrzymywano z trzciny cukrowej (Saccharum officinarum L.). Charakteryzowano go w następujący sposób: „Czysty cukier jest biały, suchy, ścisły, brzęczący, bez zapachu, słodkiego smaku, uderzając go w ciemności wydaje iskry, w wyskoku i wodzie klarownie się rozpuszcza"13.

\section{Kołaczki (trochisci, pastilli)}

\section{Definicja}

W podręczniku Formulare... Freyer opisał kołaczki jako „ciastka, stale śrzodki lékarskie zawiéraiącé"14. Dodał, że „nadaie się im za zwyczáy postać półkolistá t. i. z jednéy strony płaská, z drugiéy zaokrągloná"15. Autor wspomniał również, że dawniej nadawano tej postaci leku także inne kształty: trójkątny, czworokątny, okrągławy lub walcowaty. Kołaczki miały rozpływać się w ustach i wymagano, aby charakteryzowały się przyjemnym zapachem i smakiem ${ }^{16}$.

Odnośnie do substancji leczniczych podał:

Do formy niniéyszéy służą ciała stałé, które na proszek miałki obrócić się daią, a w smaku i woni nié mają nic odrażaiącégo, - wilgoci powietrza atmosferycznégo nié nabiéraią i nie są nadzwyczáynié dzielnémi. Prócz ciał stałych używa się i miękkich, np: Conserva Rosarum ${ }^{17}$, opiium, extraktów, - płynnych nawet np: balsamów, tynktur, oléiów i t. p. któré, ieżeli iako istotnie skuteczné w przepisie były uważané, zowią się excipienda ${ }^{18}$.

Zwrócił także uwagę na substancje pomocnicze:

ciało zaś iedynié w celu dogodzenia zamiarowi téy formy i tworzenia oneyże dodané np: cukier, kléie roślinné, syrupy, miód przaśny, krochmal, sok lukrecyiowy, czekulada i proszki z roślin oboiętnych, iako nadawaiącé tylko piérwszym żądaną formę, excipientia ${ }^{19}$.

Sacharozy według Freyera należało użyć w ilości równej masie substancji leczniczych albo dwa, a nawet trzy razy większej.

13 S. Fabian, Farmacya, t. 1, Zawierający początki botaniki i farmakologią, Warszawa 1852, s. 102. O zastosowaniu sacharozy zob. także, L. Krówczyński, Cukier w technologii postaci leku na przestrzeni wieków, „Farmacja Polska" r. 49, 1993, nr 20, s. 40-49.

14 J.B. Freyer, op. cit., s. 108.

15 Ibid.

16 Ibid., s. 108-109.

17 Conserva Rosarum sporządzano z 1 części świeżych płatków korony róży damasceńskiej (Rosa $\times$ damascena Mill.) i 2 części sacharozy przez rozcieranie w kamiennym moździerzu (Pharmacopoeia Regni Poloniae, Varsoviae 1817 , s. 102.). Róża damasceńska charakteryzuje się bardzo mocno pachnącymi kwiatami.

18 J.B. Freyer, op. cit., s. 109

19 Ibid. 
W podręczniku Skobla kołaczki zostały opisane jako „placuszki koliste, spłaszczone"20. Autor podał także następującą informację: „placuszki, nosząc na sobie pospolicie piętno gwiazdki, na piérwszy rzut oka przedstawiają podobieństwo do kółka"21.

Kołaczki można było rozgryźć i połknąć lub trzymać w ustach do rozpłynięcia się. Skobel wspomniał, że z masy przeznaczonej do wykonywania kołaczków można było wykonać również tzw. laseczki: „Jeżeli z ciasta na placuszki utoczą się cienkie wałeczki, które nadto częstokroć spłaszczają się a następnie skręcają na podobieństwo śruby, formę taką nazywamy laseczkami (bacilli)"22. Przykładem przepisu na lek recepturowy w formie laseczek jest następujący zapis:

Rp. Crocicontriti ${ }^{23}$ semidrachmam, [znamię szafranu, szafran] ${ }^{24}$

Radd. iridis florent. contrit. drachmam, [kłącze kosaćca, korzeń fiołkowy]

Radd. glycyrrhizae glabrae con-

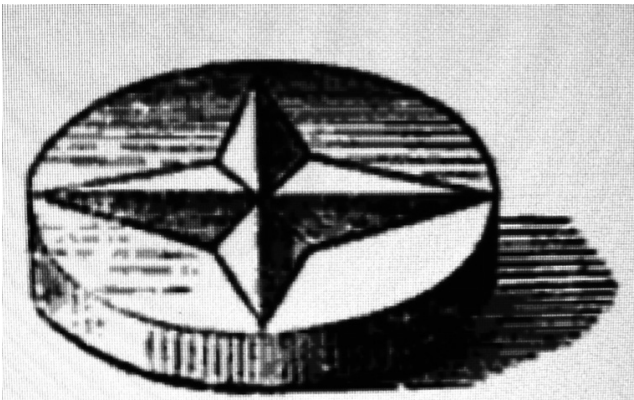

Ryc.1. Kołaczek z odciśniętym kształtem gwiazdy Źródło: H. Hager, Technik der pharmaceutischen Receptur, Lissa 1862, s. 129.

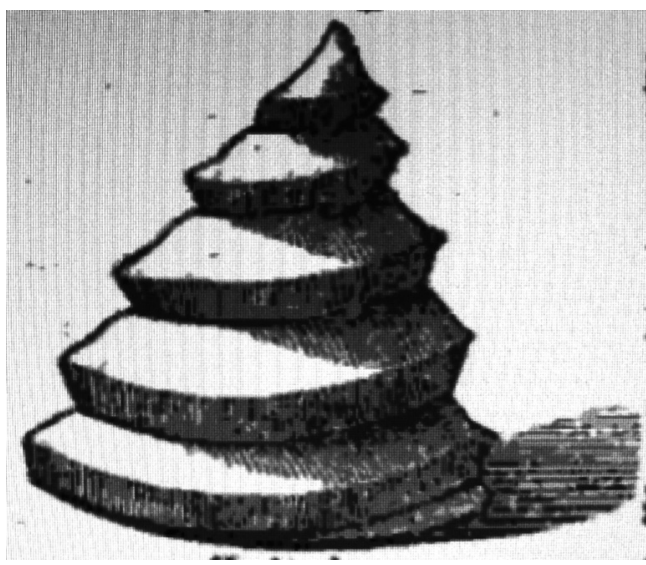

Ryc. 2. Turbinulae - kołaczek w kształcie podobnym do muszli ślimaka

Źródło: H. Hager, op. cit. s. 132. trit. semunciam, [korzeń lukrecji] Sacchari albi contr. selibram, [cukier, sacharoza, cukier trzcinowy] Mucil. gm. tragacanthae q. s. [kleik z gumy tragakantowej] ut f. I. a. bacilli, pulv. radd. glycyrrh. conspergendi, non torrendi D. S. Laseczki lakrycyjowe ${ }^{25}$.

Za przeciwwskazane w tej formie leku Skobel uznał: substancje chłonące wilgoć z powietrza (nawet przechowywane w aptece w postaci sproszkowanej), duże ilości substancji w postaci płynnej, a także o silnym działaniu i „smaku obrzydliwego"26. Jako najważniejsze substancje pomocnicze Skobel wymienił sacharozę i kleik tragankowy (tzn. tragakantowy). Sacharozy zalecał używać w ilości co najmniej dwa razy większej niż substancji leczniczych. 
Kryszka także odnotował, że kołaczki miały formę spłaszczoną i zaokrągloną; na jednej stronie oznaczoną dowolną cechą lub gwiazdką. Można je było formować także w postaci laseczki (bacilli) lub nadać im postać ślimakowatą (turbinulae).

Kołaczki były przeznaczone do podawania leków o nieprzyjemnym smaku, do których Kryszka zaliczył: proszki aromatyczne, olejki eteryczne, balsamy, wyciągi, niektóre sole mineralne. Zaznaczył jednocześnie, że ta postać leku nie jest przeznaczona dla tzw. środków gwałtownych. Ostatecznie formę leku uzyskiwano „za pomocą klejów (mucilagines), białka, syrupów, zagęszczonych soków, miazg, powidełek i najwłaściwiéj czokolady"27. Za najlepsze środki nadające spójność kołaczkom uznał gumę tragakantową (1 część gumy należało rozpuścić w 12 częściach wody) oraz „proszek ślazu” (1 część proszku łączono z 6 częściami wody). Jak poprzedni autorzy, Kryszka podał, że na jedną część substancji leczniczej używa się dwa razy więcej sacharozy.

Masa pojedynczego kołaczka mogła mieścić się w zakresie od 5 do 20 granów $(0,3-$ 1,2 gramów). Freyer wspomniał, że pojedyncze kołaczki mają zazwyczaj masę od $1 / 2$ skrupułu do 12 granów (0,6-0,72 gramów), Skobel natomiast określił ją w zakresie od $1 / 2$ skrupułu do 1 skrupułu (0,6-1,2 gramów). Kryszka zaś zalecał, aby masa kołaczków nie przekraczała 10 granów (0,6 gramów), a wyjątkowo wynosiła od 5 do 20 granów $(0,3-1,2$ gramów).

Zasadniczo w formie kołaczków nie należało przepisywać składników silnie działających, higroskopijnych i o przykrym smaku.

\section{Redagowanie recept na kołaczki}

Przepisując lek recepturowy w formie kołaczków, po skrócie $R$. albo Rp. (recipe - weź) należało wymienić substancje czynne i pomocnicze w ilości potrzebnej do wykonania wszystkich kołaczków. Na początku zapisywano substancje lecznicze, następnie sacharozę, a na końcu substancję pomocniczą wiążącą, np. kleik z gumy tragakantowej - Mucilaginis gummi tragacanthae q. s. Skrót q. s. oznaczał, że wykonujący kołaczki miał użyć tego składnika w ilości pozwalającej na sporządzenie masy o właściwej konsystencji. Po zaleceniu ut $f$. $l$. a. trochisci [aby powstały według sztuki aptekarskiej kołaczki], jeśli lek zawierał substancje silnie działające, można było określić masę pojedynczego kołaczka, zapisując np.: Formentur trochisci ponderis granorum duodecim („uformuj kołaczki o masie 12 granów"). Zazwyczaj jednak podawano liczbę kołaczków.

Poniższy przykład obrazuje zapis uwzględniający liczbę kołaczków (w tym przypadku 100 sztuk).

\section{R. Tincturae Opii simplicis [nalewka opiumowa]}

Balsami Peruviani nigri ana Dr: unam [balsam peruwiański]

Sacchari albi [cukier, sacharoza, cukier trzcinowy]

Succi Liquir pulverati ana Unc: dimidiam [zagęszczony sok lukrecjowy, nieoczyszczony wyciąg lukrecjowy] ${ }^{28}$

27 A. Kryszka, op. cit., s. 59.

28 Zagęszczony sok lukrecjowy miał „postać czarnych, twardych, cylindrycznych kawałków różnej długości i średnicy, o błyszczącym, muszlowym złomie" (Farmakopea Polska II, Warszawa 1937, s. 307-308). Charakteryzował się swoistym zapachem i słodkim smakiem. 
M: exacte F: massa e qua formentur trochisci Nro centum.

$D$ : ad scatulam.

Signa: Cztéry razy dniém iedén placuszek ${ }^{29}$.

Na recepcie zamieszczano również informację, jakiego środka użyć do posypania tej postaci leku oraz wskazówki dotyczące suszenia lub nie wykonywania tego procesu. Używano np. sformułowania: conspergendi pulvere (sacchari, lycopodii, foeniculi, anisi i t. p.) et leni igne torrendi30. Określano też rodzaj opakowania i podawano wskazówki dla pacjenta odnośnie do sposobu przyjmowania leku.

Rp. Pulv. croci, [sproszkowany szafran]

Pulv. semm. foeniculi, [sproszkowane owoce kopru]

Pulv. radd. althaeae, sing. drachmam, [sproszkowany korzeń prawoślazu]

Sacchari albi drach. sex, [cukier, sacharoza, cukier trzcinowy]

Mucilag. gm. tragacanthae q. s. [klei z gumy tragakantowej]

ut f. I. a. trochisci $X X X$

pulv. semm. foeniculi conspergdi, leniter torrendi.

D. in pyxide.

S. Podczas kaszlu, lub kiedy się nań zanosi, po jednym lub 2 kołaczyka zażywać31.

Według powyższego przepisu należało wykonać 30 kołaczków, posypać je sproszkowanymi owocami kopru, delikatnie wysuszyć i wydać w pudełku.

Zalecano, aby masa wszystkich składników na kołaczki wynosiła powyżej 1 uncji (30 gramów) ${ }^{32}$.

\section{Zasady sporządzania kołaczków}

Najdokładniejsze informacje odnośnie do wykonywania kołaczków podał w swoim podręczniku Skobel. W celu wykonania kołaczków należało wymieszać starannie substancje lecznicze z sacharozą i do tej mieszaniny dodać kleik z gumy tragakantowej, następnie wszystko ugniatać za pomocą tłuczka w moździerzu, aby otrzymać „ciasto jednostajne, dosyć tęgie" ${ }^{\prime 33}$. W dalszej kolejności dzielono je na części odpowiadające liczbie przepisanych kołaczków. Podział można było wykonać, używając przyrządu do wykonywania pigułek, który Skobel nazywał gałecznicą. Z poszczególnych części palcami formowano gałeczki, posypywano je odpowiednim proszkiem i spłaszczano za pomocą stempla (na stemplu mógł być umieszczony $\mathrm{np}$.

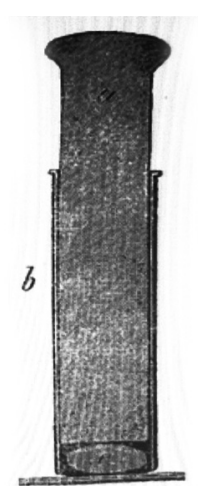

Ryc. 3. Przyrząd do sporządzania kołaczków ze stemplem

Źródło: H. Hager, op. cit. s. 125. 


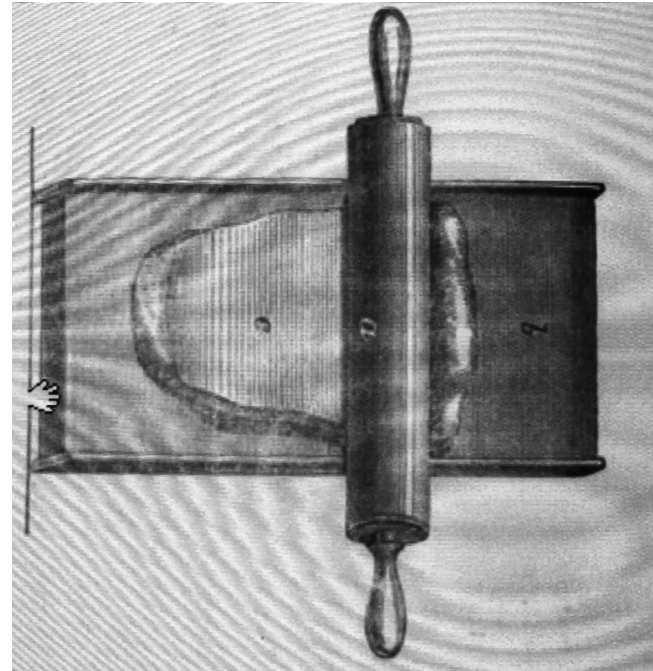

Ryc. 4. Przyrząd do rozwałkowania masy do sporządzania kołaczków

Źródło: H. Hager, op. cit.. s. 126. znak gwiazdki lub kwiatka).

Innym sposobem było rozwałkowanie masy o odpowiedniej grubości i wykrawanie $z$ niej za pomocą specjalnego przyrządu kolistych placuszków. Skobel wspomniał również, że we Francji rozwałkowaną masę krajano na części w kształcie czworokątów.

Po uformowaniu kołaczków należało je wysuszyć, używając odpowiedniego piecyka. Można było suszenie przeprowadzić także w rurze od pieca lub w łaźni piaskowej. Nie wykonywano tego, jeśli lek zawierał substancje lotne, łatwo rozkładające się lub takie, które miękły w cieple.

Odnośnie do wykonania kołaczków Kryszka podał: „Chociaż kołaczki zawie-

rają w sobie cukier, uprzyjemniający rozpływanie się ich w ustach, nie przysposabiają się na ogniu, tylko wymienione środki zarabiają się w massę ciastowatą"34 za pomocą odpowiednich substancji pomocniczych. Tak, jak Skobel podał, że z masy otrzymanej z substancji leczniczych i pomocniczych toczono wałeczek i dzielono na równe części „na maszynce pigułkowéj"35, a „pojedyncze kawałki, dotąd nie zbyt przywozicie w palcach lub na dłoni zaokrąglane i spałaszczane, na jednéj stronie naznaczają się dowolną cechą albo gwiazdką. Niekiedy ciasto rozgniata się równo, a pojedyncze kołaczki stosowném żelazkiem wycinają"36.

Kołaczki zwykle wydawano w pudełkach, a te, które poddawano suszeniu można było umieścić również w papierowej torebce. Skobel określił je jako formę leku łatwą do przechowywania ${ }^{37}$.

\section{Morsele (morsuli) czyli tabliczki (tabellae)}

\section{Definicja}

W opracowaniu Freyera morsele scharakteryzowano jako stałą formę leku w kształcie „równoległoboków lub czworogranów ukośnych" ${ }^{38}$, przeznaczoną do żucia. Mogły one zawierać substancje lecznicze w postaci proszków, ale niepochłaniających wilgoci, a także składniki o miękkiej konsystencji, jak np. konserwa różana (Conserva Rosarum) lub płynne: olejki eteryczne oraz soki (np. cytrynowy, malinowy, porzeczkowy). Substan-

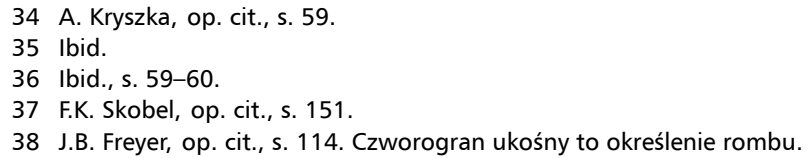


cją pomocniczą w tej postaci leku był, jak to określił Freyer, „raz na zawsze cukier" ${ }^{39}$. Na 1 część substancji leczniczej zalecał użycie od 3 do 6 części sacharozy. W przypadku użycia leków w formie płynnej sacharozy należało zastosować mniej. Nie zalecano do morseli składników o przykrym smaku i zapachu oraz o silnym działaniu (ze względu na możliwość niedokładnego rozmieszczenia substancji leczniczych w poszczególnych morselach, a w związku z tym niedokładność dawkowania).

Morsele według Skobla były to tabliczki czworokątne o długości kilku cali i szerokości pół cala lub 1 cala $(2,4 \mathrm{~cm})$, a grubości 2-3 linii $(4-6 \mathrm{~mm})$. „Przed połknięciem morsele częścią się gryzą, częścią same przez się rozpływają się w ustach"40. Mogły zawierać substancje lecznicze w postaci stałej - głównie surowce roślinne sproszkowane lub przynajmniej drobno posiekane (kory, owoce, nasiona). W ich skład mogły chodzić także kwaśne soki owocowe. Nie należało używać tzw. proszków kruszcowych ciężkich, ze względu na możliwość opadania na spód naczynia (podczas zastygania masy podczas sporządzania tej formy leku), a także lepkich (np. żywic), substancji pochłaniających wilgoć z powietrza, jak również silnie działających i o nieprzyjemnym smaku. Olejki eteryczne zalecano używać w ilości dwa razy większej od przewidzianej dawki ze względu na możliwość ulotnienia się w podwyższonej temperaturze. Można też było gotowe morsele „pomazać rozczynem obranego oleju lotnego w eterze, lub skropić je takim roztworem, lub wreszcie po kropli pomienionego oleju puścić na każden morselek"41.

Podobny opis podał Kryszka, zaznaczając, że morsele „są mięszaniną środków lekarskich, najczęściéj roślinnych z cukrem gotowanym, po stężeniu pokrajaną w tabliczki, od jednéj do trzech drachm ważące. Do rzeczonych kąsków biorą się: owoce, kwiaty, kory, korzenie, soki roślinne, niektóre sole mineralne, wszystkie bez wyjątku nieodznaczające się silniejszém działaniem na organizm ludzki, najczęściéj aromatyczne, posiekane lub sproszkowane"42.

Masa pojedynczej morseli mogła wynosić od 1 do 3 drachm (od 3,75 do 11,25 gramów) $)^{43}$.

\section{Redagowanie recept na morsele}

W przepisach na lek recepturowy w formie morseli na początku, według Freyera, umieszczano informację odnośnie do sacharozy i sposobu postępowania z nią, a następnie substancje lecznicze.

R. Sacchari albi in aquae font. q: s: soluti Unc: quinque [cukier, sacharoza, cukier trzcinowy; Aqua fontana - woda studzienna] coque ad consistentiam tabulandi, dein adde Magnesiae ustae Unc: unam [tlenek magnezowy, magnezja palona] Ferri oxydulati nigri Dr: unam [tlenek żelazowo-żelazawy] Funde in modulos idoneos 


\section{F: morsuli ponderis aequalis Nro xxiv \\ $D:$ ad scalutam.}

Signa: W czasie potrzeby po iednéy używać44.

Według powyższego przepisu sacharozę należało rozpuścić w wodzie i zagotować do odpowiedniej konsystencji, następnie dodać substancje lecznicze i otrzymaną masę wylać do odpowiednich form i wykonać 24 morsele o jednakowej masie.

Skobel także podał, że można na początku podać informacje na temat sacharozy, a następnie wymienić substancje czynne. Inny sposób przepisywania uwzględniał podanie w pierwszej kolejności substancji leczniczych, a w dalszej substancji pomocniczych. Przy sacharozie wpisywano wtedy skrót q. s. Adnotacja f. l. a. morsuli (fiat lege artis morsuli) oznaczała zalecenie wykonania morseli według sztuki aptekarskiej.

Masa wszystkich składników przepisanych na morsele wynosiła od 4 do 6 uncji (od 120 do 180 gramów) ${ }^{45}$.

\section{Zasady sporządzania morseli}

Podobnie jak w przypadku kołaczków, wskazówki związane ze sporządzaniem morseli najdokładniej podał Skobel. Przy wykonywaniu morseli, które zawierały substancje lecznicze w postaci stałej, należało 1 część sacharozy rozpuścić w 1/4 części wody i zagotować, a następnie, według Skobla:

wypienić a wreszcie warzyć nagle (przy mocnym ogniu), nie mięszając go wcale, aż dopóki nie nabierze gęstości, która go zdatnym czyni do robienia zeń tabliczek („ad spissitatem" albo wcale „ad consistentiam tabulandi”), albo używając innego wyrazu, dopóki cukier nie pocznie się pierzyć lub prząść, t. j. dopóki jakaś cząstka jego, wyjęta z naczynia za pomocą kopystki i nagle mieciona w powietrze, nie nastrzępi się jak piérze; albo ściekając z niéj, nie utworzy długiéj cienkiéj nici ${ }^{46}$.

Freyer odnośnie do oceny konsystencji masy do wykonania morseli podał, że należy uznać ją za właściwą, „gdy nitki w które kropla spuszczoná się ciągnie, na powietrzu wol-

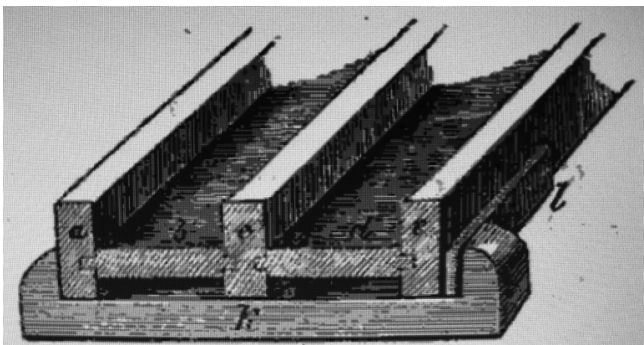

Ryc. 5. Forma do sporządzania morseli Źródło: H. Hager, op. cit., s. 135. ném stężeią (justa tabellarum v. tabulandi consistentia)" 47 . Kryszka z kolei zalecał określać ją poprzez wyrzucenie w powietrze za pomocą łopatki małej ilości gotującej się cieczy. Jeśli nie rozpadała się w tzw. kłaczki, uważano ją za właściwą.

Po otrzymaniu cieczy odpowiedniej konsystencji naczynie natychmiast odstawiano od ognia, a jego zawartość mieszano kopystką „dopóki cukier nie- 
przezroczysty na ścianach jego osiadać nie pocznie"48. Wówczas dodawano uprzednio przygotowane i zmieszane ze sobą substancje lecznicze, dokładnie mieszano i masę wylewano do powleczonych olejem migdałowym lub zwilżonych wodą drewnianych form (moduli), które Skobel nazwał korytkiem. Kryszka z kolei przygotowaną masę zalecał wylewać do form papierowych, powleczonych olejem migdałowym ${ }^{49}$.

Substancje lecznicze do opisywanej postaci leku określano jako species morsuli. Były to np.: „migdały, skórka cytrynowa, pomarańczowa, cynamon, galanga, cytwar czyli gliśnik)" ${ }^{\prime 2}$. Dodawano je bez wcześniejszego rozdrobnienia lub po uprzednim sproszkowaniu lub tylko po potłuczeniu albo po posiekaniu. Stanowiły zazwyczaj $1 / 4$ lub $1 / 6$ część sacharozy. Po zastygnięciu, ale jeszcze ciepłą masę, dzielono nożem na „żądanej wielkości tabliczki"51 w liczbie wskazanej na recepcie.

W przypadku sporządzania morseli z kwaśnymi sokami owocowymi należało postępować w następujący sposób: „cukier miałki na sucho ogrzéwać w naczyniu przy wolnym ogniu, mieszając go ciągle, dopóty, dopóki włożonego weń palca bez bólu utrzymać w nim nie można; co gdy się stało, wléwa się doń tyle soku, ile potrzeba, aby gąszcz ten, nie warząc go już wcale, nabrał przyzwoitéj gęstości; t. j. na 8 części cukru na wagę, jedna część soku"52. Na końcu wylewano taką masę do form i postępowano jak podano powyżej.

Każdą morselę należało oddzielnie zawinąć w papier i włożyć do pudełka.

Krążki (rotulae, orbiculi)

\section{Definicja}

Freyer w swoim podręczniku odnotował, że krążki miały kształt półkolisty, „powinné bydź przyświecaiącémi i zamiast proszków lub konfektu ${ }^{53}$, tylko soki roślinné przyiemné, oraz oléie eteryczné zawiérać" 54 .

Skobel scharakteryzował krążki jako „placuszki koliste, zwykle po jednéj stronie wypukłe (mogące być uważane za odcinki spłaszczone gałeczki, albo téż za bardzo nizkie wałeczki, średnicy kilku linii), złożone z właściwych leków, jako przyjątków i stężałego roztworu cukru, jako objątka" 55 . Według Skobla w tej formie można było zapisać oprócz kwaśnych soków owocowych i olejków eterycznych także substancje w postaci proszku. $\mathrm{Na}$ temat tych ostatnich autor nadmienił: „muszą być nierównie mieléj utłuczone i musi ich być nierównie mniéj, aniżeli w morselach"56.

Substancje lecznicze, mogące wchodzić w skład małych cukrowych krążków, wymienione przez Kryszkę, to: soki roślinne, olejki eteryczne, naciągi, a bardzo rzadko proszki. Na

53 Konfekt (electuarium s. electarium) „jest formą do użytku wewnętrznégo iedynie przeznaczoną, konsystencyi gęstawo-płynnéy, pospolicie z ciał stałych i płynnych złożoną" (J.B. Freyer, op. cit., s. 219). Dawniej, jeśli w jego skład wchodziły konfitury stosowano nazwę confectio, a jeśli opium używano określenia opiatum (ibid.).

54 Ibid., s. 117.

55 K.F. Skobel, op. cit., s. 154.

56 lbid., s. 155. 
2 uncje (60 gramów) sacharozy zalecał użycie 2 drachm (7,5 gramów) proszków, 1,5 drachmy (5,63 gramy) soków, naciągów, spirytusów lub od 10 do 20 kropli olejków eterycznych.

Freyer zalecał sporządzanie krążków o masie od 2 do 5 granów (0,12-0,3 gramów), a rzadko o większej niż 5 granów, Skobel natomiast od 5 do 10 ziarn, tzn. gran $(0,3-$ 0,6 gramów).

\section{Redagowanie recept na krążki}

Przepisując receptę na krążki, na początku można było wymienić sacharozę i wodę lub sok owocowy, zaznaczając, w jaki sposób należy postąpić z tymi składnikami, a następnie wymienić pozostałe składniki leku.

Rp. Sacchari albi pulv. Unc. duas. [cukier, sacharoza, cukier trzcinowy]

Succi citri rec. expressi Dr. duas. [sok cytrynowy]

calefactis leni igne adde

Elaeosacch. flaved. citri Drach. unam [olejkocukier cytrynowy]
F. I. a. Rotulae
D. in scatula
S. używać podług upodobania ${ }^{57}$.

Według powyższej recepty sproszkowaną sacharozę ze świeżo wyciśniętym sokiem z cytryny należało ogrzać na wolnym ogniu i dodać olejkocukier cytrynowy.

Redagując przepis na lek recepturowy, w skład którego wchodził olejek eteryczny, można było wskazać liczbę krążków wcześniej przygotowanych tylko z sacharozy, a następnie podać nazwę olejku eterycznego.

Ogólna masa składników, jaką należało przepisać na krążki, to około 2 uncje (60 gramów).

\section{Zasady sporządzania krążków}

Krążki z substancjami leczniczymi w postaci proszku wykonywano gotując na początku roztwór sacharozy w wodzie do odpowiedniej konsystencji, którą sprawdzano umieszczając kroplę masy np. na kamiennej zimnej płycie. Jeśli masa natychmiast tężała, wówczas dodawano do niej substancje czynne i po wymieszaniu kroplami umieszczano ją na płycie powleczonej olejem. Skobel ujął to w następujący sposób:

owa mięszanina [...] spuszcza się na zimny płyt kruszcowy. Tym właśnie sposobem poswatają kółeczka; które, gdy zastygną, odrywają się od płytu, a żeby wyschły zupełnie, rozpościerają się na arkuszu papieru i wraz z nim wkładają się do rzeszota $^{58}$.

Zaznaczył, że dla sproszkowanych substancji leczniczych lepszą formą leku były morsele (ze względu na możliwość wprowadzenia do nich składników stałych w większej ilości). 
W podany sposób wykonywano również krążki bez substancji leczniczych i nazywano je krążkami prostymi (rotulae sacchari).

Krążki, w skład których wchodziły kwaśne soki owocowe, a według Freyera "soki roślinné przyiemné"59, sporządzano ogrzewając na początku tylko sacharozę do momentu, „aby jeszcze tam palec można było utrzymać" 60 , po czym dodawano soki i po wymieszaniu kroplami umieszczano na płycie jak opisano powyżej. Masa soku zazwyczaj stanowiła w krążku 1/8 masy sacharozy.

Krążki wykonywano również z olejkami eterycznymi. Używano na ogół 1 kroplę olejku eterycznego na 1 skrupuł (1,2 grama) sacharozy ${ }^{61}$. Ze względu na możliwość ulotnienia się tego składnika pod wpływem ciepła w trakcie sporządzania krążków wymienionymi metodami proponowano $\mathrm{np}$. umieścić rotulae sacchari w słoju zwilżonym olejkiem eterycznym. Skobel podał, że w trakcie wstrząsania olejek eteryczny przenikał do tzw. kółeczek prostych, jednak nierównomiernie. W celu zapewnienia większej dokładności w nasycaniu krążków olejkiem eteryczny zalecano zastosowanie olejku eterycznego rozcieńczonego taką samą ilością (lub dwa razy większą) substancji lotnej, np. eteru dietylowego (Aether sulfuricus) ${ }^{62}$ lub eteru octowego (Aether aceticus) ${ }^{63}$, nazywanego też naftą octową (Naphta acetica) ${ }^{64}$.

Nieco inny sposób odnotował Kryszka, wspominając, że najczęściej przygotowuje się tylko rotulae sacchari i „dopiéro później, do szklanego naczynia zakrytego, niemi napełnionego, wkłada się bibułka filtrowa napojona żądaną ilością oleju eterycznego (mięty, tataraku, rumianku), im właściwego zapachu udzielającego" ${ }^{\prime 65}$. Jednak ten sam autor podał też: „co lepiéj, 1 część oleju eterycznego roztwarza się 3 częściami eteru i roztworem tym skrapiają się zamknięte w naczyniu krążki cukrowe"66.

Znane powszechnie były krążki miętowe (rotulae menthae piperitae) ${ }^{67}$ przygotowywane w aptekach na zapas.

Opakowaniem dla krążków były pudełka.

\section{Podsumowanie}

Różnice w ujęciu kwestii wskazanych w tytule artykułu w poszczególnych podręcznikach wynikały ze stanu wiedzy dostępnej w określonym czasie oraz własnych zainteresowań autorów i ich różnej koncepcji prezentacji zagadnień.

59 J.B. Freyer, op. cit., s. 117.

60 A. Kryszka, op. cit., s. 57.

61 J.B. Freyer, op. cit., s. 117.

62 Freyer zaznaczył, że olejek eteryczny, aby zapobiec jego ulatnianiu się, „zamiast domieszania do gorącégo cukru, rozpuściwszy w eterze do sporządzonych z samégo cukru kółeczek, dodawać zaleca się" (ibid., op. cit., s. 118).

63 Nazwę eter octowy dawniej stosowano dla octanu etylu - Aethylium aceticum (octan etylowy, ester etylowy kwasu octowego) - „bezbarwna, przezroczysta ciecz o swoistym, owocowym, orzeźwiającym zapachu” (Farmakopea Polska II, Warszawa 1937, s. 105).

64 F.K. Skobel, op. cit., s. 156.

65 A. Kryszka, op. cit., s. 58.

66 Ibid.

67 J.B. Freyer, op. cit., s. 118; F.K. Skobel, op. cit., s. 155; A. Kryszka, op. cit., s. 58. Przepis na krążki miętowe znajdował się np. w Pharmacopoea Borussica (editio sexta, Berolini 1846, s. 204). 
Wybrane postacie leku różniły się masą (najmniejszą posiadały krążki, a największą morsele), kształtem (także w obrębie danej postaci leku, np. kołaczki mogły posiadać formę małego, płaskiego walca lub kształt podobny do muszli ślimaka) i sposobami sporządzania. Istniało podobieństwo w wytwarzaniu morseli i krążków, a autorzy przy opisach krążków odwoływali się do informacji podanych na temat morseli.

Postacie leku z grupy tzw. łakotek lekarskich były zalecane do stosowania dla dzieci i chorych dorosłych, którzy mieli trudności w przyjmowaniu leków. Należały one także do droższych form leku. Na przykład odnośnie do kołaczków Freyer podał, że mają one zastosowanie dla szczególnej grupy pacjentów: „Wstręt uroiony lub rzeczywisty zwłaszcza u dzieci i ułożenie dziecinné maiących dorosłych"68. Były one uważane za dogodną formą leku w terapii chorób przewlekłych ${ }^{69}$.

Kołaczki po rozgryzieniu można było połknąć lub trzymać w ustach do rozpłynięcia się. Morsele przed połknięciem zalecano żuć (częściowo też same rozpływały się w ustach). Krążki natomiast należało trzymać w ustach do rozpłynięcia się. Ze względu na sposób zażywania tych form leku zwracano uwagę na stosowanie w nich substancji leczniczych o działaniu miejscowym w jamie ustnej. Na przykład lek o poniżej podanym składzie zalecano stosować w przypadku nieprzyjemnego zapachu z ust.

Rp. Vanillae contritae drachmam, [owoce wanilii płaskolistnej]

Carbonis ppti unciam, [węgiel drzewny]

Chocolatae contritae, [czekolada]

Sacchari albi. utriusque sescunciam, [cukier, sacharoza, cukier trzcinowy]

Mucil. gm. tragacanthae q. s. [kleik z gumy tragakantowej]

ut f. trochisci XVIII, pulv. cassiae cinnamom. conspergdi, leni calore exiccandi.

D. S. 3-4 razy dnia po 2 placuszka brać do ust, i trzymać je póki się zwolna nie rozpuszczą ${ }^{70}$.

Formy leku z grupy łakotek lekarskich mogły być też używane w schorzeniach przewodu pokarmowego, jak podano w poniższym przykładzie.

Rp. Natrii bicarbonici contriti unciam, [kwaśny węglan sodowy, dwuwęglan sodowy]

Sacchari albi contriti unc. duas, [cukier, sacharoza, cukier trzcinowy]

(Olei cinnamomi gutt. sex), [olejek cynamonowy] ${ }^{71}$

Mucil. gm. mimosae q. s. [kleik z gumy arabskiej]

ut $f$. trochisci $L X X X X V I$, pulvere cassiae cinnam. conspergendi, non torrendi.

D. in pyxide.

S. Podczas niestrawności ze zgagą niekiedy po jednym kołaczyku zażywać72.

68 J.B. Freyer, op. cit., s. 111.

69 F.K. Skobel, op. cit., s. 151.

70 Ibid., s. 153.

71 W Farmakopei Polskiej II przy określaniu nazw olejków eterycznych używano tylko słowa olejek (ten sposób nazewnictwa zastosowano również w niniejszej pracy).

72 F.K. Skobel, op. cit., s. 152. 
Według autorów wybranych podręczników kołaczki, morsele i krążki sporadycznie były przypisywane jako leki recepturowe ${ }^{73}$. Za najczęściej używaną postać leku spośród tzw. przypraw aptecznych uważano kołaczki ${ }^{74}$. Przepisy na opisane postaci leku zamieszano także w farmakopeach, a lekarz przepisujący receptę na preparat farmakopealny, podawał nazwę leku i liczbę sztuk danej postaci leku5.

\section{Bibliografia}

Fabian S., Farmacya, t. 1, Zawierający początki botaniki i farmakologią, Warszawa 1852. Freyer J.B., Formulare czyli nauka o sztuczném przepisywaniu lekarstw, Warszawa 1816. Kryszka A., Receptura czyli nauka pisania recept i przyrządzania podług nich lekarstw, Warszawa 1865.

Skobel F.K., Wykład farmakomorfiki i katagrafologii, Kraków 1851.

Dr n. farm. ELŻBIETA RUTKOWSKA pracuje w Zakładzie Farmacji Stosowanej Uniwersytetu Medycznego w Białymstoku. Jej zakres zainteresowań badawczych obejmuje historię farmacji, a szczególnie historię technologii postaci leków, historię leku roślinnego oraz historię aptekarstwa w XIX i XX w. E-mail:elzbieta.rutkowska@umb.edu.pl

73 Na przykład Skobel podał: „Tak kołaczyki i morsele, tak téż i krążki, zwłaszcza zawierające w sobie jakiś proszek lekarski lub sok owocowy, obecnie rzadko tylko bywają używane, a jeszcze rzedziéj przepisywane umyślnie pewnym chorym" (ibid., s. 156). Szczególnie o morselach wspomniał jako niesłusznie rzadko stosowanej wówczas formie leku (ibid., s. 160).

74 A. Kryszka, op. cit., s. 59.

75 Niemniej jednak w Pharmacopoeia Regni Poloniae (Varsoviae 1817), uznawanej za pierwszą narodową farmakopeę polską, nie zamieszczono przepisów na postacie leku opisywane w tej pracy (istnieje w niej co prawda opis Trochisci Alhandal (Colocynthis praeparata), ale ostatecznie preparat ten miał postać proszku). 